\title{
Erratum to: An "Accidental Profession": Small Press Publishing in the Pacific Northwest
}

\author{
Melanie Ramdarshan Bold ${ }^{1}$
}

\section{Erratum to: Pub Res Q \\ DOI 10.1007/s12109-016-9452-9}

The surname of the author of the published article is incorrectly listed in references [20] and [24]. The surname is not "Bold", but rather is "Ramdarshan Bold" as listed in the corrected references [20] and [24].

\section{References}

20. McCleery A, Ramdarshan Bold M. 'What is my country?': Supporting small nation publishing. J Irish Scott Stud. 2012;6(1):115-32.

24. Ramdarshan Bold M. The rights and wrongs of operational practices in the Scottish publishing industry. Publ Res Q. 2012;28(4):345-58.

The online version of the original article can be found under doi:10.1007/s12109-016-9452-9.

Melanie Ramdarshan Bold

m.bold@ucl.ac.uk

1 Department of Information Studies, University College London, Foster Court, Gower Street, London WC1E 6BT, UK 